\title{
Virtual water trade patterns in relation to environmental and socioeconomic factors: A case study for Tunisia
}

\author{
Hatem Chouchane ${ }^{\mathrm{a}, *}$, Maarten S. Krol ${ }^{\mathrm{a}}$, Arjen Y. Hoekstra ${ }^{\mathrm{a}, \mathrm{b}}$ \\ a Water Engineering E Management, University of Twente, Enschede, The Netherlands \\ ${ }^{b}$ Institute of Water Policy, Lee Kuan Yew School of Public Policy, National University of Singapore, 259770, Singapore
}

\section{H I G H L I G H T S}

- The yearly water footprint of main crops in Tunisia is calculated using AquaCrop.

- The dynamics in net virtual water import (NVWI) are analysed over 30 years.

- Blue water scarcity does not explain NVWI dynamics of any of selected crops.

- Import of staple crops can be better explained than export of cash crops.

\section{G R A P H I C A L A B S T R A C T}

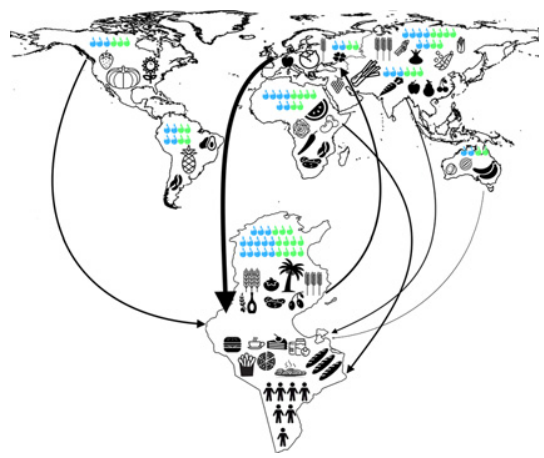

\begin{abstract}
A B S T R A C T
Growing water demands put increasing pressure on local water resources, especially in water-short countries. Virtual water trade can play a key role in filling the gap between local demand and supply of water-intensive commodities. This study aims to analyse the dynamics in virtual water trade of Tunisia in relation to environmental and socio-economic factors such as GDP, irrigated land, precipitation, population and water scarcity. The water footprint of crop production is estimated using AquaCrop for six crops over the period 1981-2010. Net virtual water import (NVWI) is quantified at yearly basis. Regression models are used to investigate dynamics in NVWI in relation to the selected factors. The results show that NVWI during the study period for the selected crops is not influenced by blue water scarcity. NVWI correlates in two alternative models to either population and precipitation (model I) or to GDP and irrigated area (model II). The models are better in explaining NVWI of staple crops (wheat, barley, potatoes) than NVWI of cash crops (dates, olives, tomatoes). Using model I, we are able to explain both trends and inter-annual variability for rain-fed crops. Model II performs better for irrigated crops and is able to explain trends significantly; no significant relation is found, however, with variables hypothesized to represent inter-annual variability.
\end{abstract}

(c) 2017 Elsevier B.V. All rights reserved.

\footnotetext{
* Corresponding author.

E-mail addresses: hatemchouchane1@gmail.com, h.chouchane@utwente.nl (H. Chouchane).
}

\section{Introduction}

Demands for freshwater in agriculture increase, while renewal rates are finite, which makes water a limiting factor in food production in several countries. Water-short countries are increasingly meeting their food requirement through import instead of domestic production 
(Marianela et al., 2013). By importing food, these countries import 'virtual water', which refers to the water virtually embedded in traded products (Allan, 1998). Importing food shifts local water use to the use of water abroad (Hoekstra and Hung, 2005). Closely linked to the idea of virtual water trade is the concept of water footprint (WF), an indicator of fresh water use from either the consumer or producer point of view (Hoekstra, 2017). The WF has three components: blue, green and grey. The blue WF refers to consumption (net abstraction) of blue water resources (surface and groundwater); the green WF refers to consumption of green water resources (rainwater stored in the soil); the grey WF indicates water pollution and is defined as the volume of freshwater that is required to assimilate a load of pollutants, given natural background concentrations and existing ambient water quality standards (Hoekstra et al., 2011). Virtual water trade through food trade thus plays an important role in compensating for the gap between local demand and supply of water-intensive commodities (Antonelli and Sartori, 2015).

A few authors have tried to explain trade patterns in relation to the endowment of production factors, like water availability (the freshwater available for use within country's borders from surface water or groundwater). Yang and Zehnder (2002) presented the case of six southern Mediterranean countries; they demonstrated statistically the significant role that international trade in grains and other agricultural products has played to achieve food security in those countries, and in compensating local water deficits. In a subsequent study, Yang et al. (2003) modelled the relationship between water resources availability and cereal import for Asian and African countries; they showed that the GDP per capita is highly significant in explaining the variations in the level of cereal imports among countries with similar availability of water resources. Kumar and Singh (2005) analysed relations between renewable freshwater availability and net virtual water trade of 146 countries across the world, finding none of them to be significant. Yang and Zehnder (2007) focused on the southern and eastern Mediterranean countries in order to investigate in more detail the relations between water availability and crop trade for different crops. They found that during the last two decades the decline in per capita water resources availability was a dominant factor in explaining the increase in the import of water-intensive crops. Tamea et al. (2014) investigated the drivers of virtual water fluxes associated with international food trade using a gravity-law model over 25 years. They found that GDP and distance are the fundamental controlling factors of virtual water trade, both for import and for export, while the arable land does not give a significant contribution. In a more recent study, Fracasso et al. (2016) investigate the determinants of the bilateral virtual water trade in the Mediterranean basin. The study showed that larger water endowments do not necessarily lead to larger export of waterintensive products.

Over the last decade, many authors estimated the virtual water embedded in traded products (Aldaya et al., 2010; Chapagain and Hoekstra, 2008; Hanasaki et al., 2010; Hoekstra and Hung, 2005). Other authors have estimated the amount of saved water by countries due to their engagement in virtual water trade (Chapagain et al., 2006; Fader et al., 2011; Konar et al., 2013). Some authors made estimates in economic terms quantifying the cost and gain per $\mathrm{m}^{3}$ as a result of virtual water import and virtual water export respectively (Chouchane et al., 2015; Mekonnen and Hoekstra, 2014; Schyns and Hoekstra, 2014). However, it has not been very common for water sector specialists to consider the relation between water availability in a region and import into and export from that region (Hoekstra, 2013). Furthermore, most virtual water trade studies have been carried out for a specific year, an average over years or a short period of years (Zhuo et al., 2016). The effect of inter-annual variability and trends in environmental, social and economic factors on temporal patterns of virtual water trade has hardly been studied (Zhuo et al., 2016).

The aim of this paper is to analyse trends and inter-annual variability in virtual water trade for Tunisia in relation to environmental and socio- economic factors such as gross domestic product, population, irrigated land, precipitation, and water scarcity. Water scarcity refers here to the ratio of annual blue water consumption (blue WF) to annual blue water availability (total renewable water resources). We choose Tunisia as a case study since it is a severely water-scarce country where water resources are unevenly distributed due to the spatial differences in climate between the north, centre and south of the country (Chouchane et al., 2015). The investigation is made for a selection of main crops based on water productivity (defined as the crop yield over the volume of water consumed), volume of production, and volume of trade. From an economic perspective, a water-scarce country could be expected to trade such that it mitigates the pressure on its domestic freshwater resources; the analysis carried out here will diagnose to which extent this holds for Tunisia. The water footprint is estimated for the selected crops over the period 1981-2010 at a daily basis and spatial resolution of $5 \times 5$ arc minute following the method described in The Water Footprint Assessment Manual (Hoekstra et al., 2011). Virtual water trade is quantified at yearly basis. Regression models are used to investigate dynamics in virtual water trade over the years in relation to various environmental and socio-economic factors.

The current paper adds to the existing literature by analysing the dynamics in net virtual water import from a water-scarce country perspective. All other studies focussed on bilateral trade and/or crosscountry analysis and did not clearly relate virtual water trade of a country to its internal factors like its blue water scarcity. The reason for undertaking the study is to explore in more detail than previous studies whether we can establish a relation between long-term trends and inter-annual variability in net virtual water import and possibly explanatory factors within the country.

\section{Method and data}

In order to analyse the trend and inter-annual variability in virtual water trade, a multiple regression model is used. The regression analysis is performed for selected crops in Tunisia (listed in Table 1). We consider the two most consumed staple crops of Tunisia (wheat and barley, which together account for $50 \%$ of the daily food supply in kcal per capita in 2010; FAOSTAT, 2015), the two most important cash crops for Tunisian export (olives and dates, which together account for $45 \%$ of the total agricultural export value in 2010; FAOSTAT, 2015), and the two crops with highest economic blue water productivity in the country (tomatoes and potatoes; see Chouchane et al., 2015). Wheat and barley are mainly rain-fed and net imported. Olives are rain-fed and dates are mainly irrigated. Both tomatoes and potatoes are mainly irrigated, while tomatoes are exported to a little extent and potatoes are mainly imported (Ministry of Agriculture, 2011). The broad variety of main crops (rain-fed - irrigated, mainly exported - mainly imported, and high and low water productivity) supports the choice of Tunisia as a case study. In order to assess the yearly water footprint of the selected crops during the period 1981-2010, we make use of FAO's soil water balance and crop productivity model AquaCrop (Steduto et al., 2009).

\section{Table 1}

Average annual production, percentage of irrigated production in total production and net import of the selected crops (1981-2010).

\begin{tabular}{lllll}
\hline Crop & $\begin{array}{l}\text { Average annual } \\
\text { production }\left(10^{3}\right. \\
\text { tonne/year })^{\mathrm{a}}\end{array}$ & $\begin{array}{l}\text { Percentage irrigated } \\
\text { production in total } \\
\text { production }(\%)^{\mathrm{a}}\end{array}$ & $\begin{array}{l}\text { Net import }\left(10^{3}\right. \\
\text { tonne/year) }\end{array}$ & $\begin{array}{l}\text { Economic } \\
\text { blue water } \\
\text { productivity } \\
\left(\mathrm{US} \$ \mathrm{~m}^{3}\right)^{\mathrm{b}}\end{array}$ \\
\hline Wheat & 1100 & 22 & 1100 & 0.12 \\
Barley & 390 & 22 & 280 & 0.04 \\
Potatoes & 250 & 98 & 30 & 0.97 \\
Olives & 720 & 39 & -100 & 0.03 \\
Dates & 95 & 100 & -30 & 0.11 \\
Tomatoes & 690 & 100 & -2.2 & 1.13 \\
\hline
\end{tabular}

a Ministry of Agriculture (2011).

b Chouchane et al. (2015). 


\subsection{Regression model}

We made similar selections of variables to explain differences in international virtual water trade (VWT) as in previous studies using regression models (Table 2). Water availability, GDP and irrigated land are the variables that are commonly used to explain VWT. In previous studies, water availability referred to blue water availability. Variables representing constraints in green water resources have generally been neglected; however, including green water resources is important in national and regional water resources accounting and in the analysis of water and food relations (Yang and Zehnder, 2007).

In the current study, we adopt a multiple regression approach as in the three previous studies listed in Table 2 . This gives the opportunity to analyse the variability in the dependent variable (net virtual water import) in relation to possible independent explanatory variables at the same time and yields an understanding of the association of the set of independent variables as a whole with the dependent variable, and the associations between the various independent variables themselves (Marill, 2004). Other studies used gravity-law models in order to investigate drivers of virtual water trade (Fracasso et al., 2016; Tamea et al., 2014). Gravity-law models are used to investigate the spatial patterns of trade, while in the current study we aim to investigate how VWT of one country relates to possible drivers within the country. With respect to earlier multiple regression studies aimed at understanding VWT, a few changes are made here. In addition to GDP and irrigated land, some variables that may explain inter-annual variability will be included. Precipitation is added to cover the green part of the water availability. To check the impact of water scarcity on VWT, a variable of blue water scarcity at national level is integrated into the model. Blue water scarcity is defined as the ratio of total blue water footprint of domestic crop production to total blue water resource availability (Chouchane et al., 2015). The total blue water footprint is estimated by the blue water footprint related to production of the selected crops, dominating the blue WF in Tunisia according to Chouchane et al. (2015). The blue water availability is taken from the Tunisian Ministry of Agriculture (1981-2010a), which reports the amount of water available for exploitation (economically available).

To analyse virtual water trade patterns, we develop multiple regression models to explain net virtual water import (NVWI, the dependent variable) in relation to five selected independent variables: population, GDP, irrigated land, precipitation, and water scarcity level. When we find high collinearity between the independent variables (dependencies between independent variables), we develop different regression models, taking in each model a different subset of the independent variables, minimising collinearity in each model (Table 2). The advantage of testing more than one regression model is that we can test a number of hypotheses (presented hereafter).

The multiple regression equation with all variables looks as follows:

$\mathrm{NVWI}=\alpha+\beta_{1} \mathrm{POP}+\beta_{2} \mathrm{GDP}+\beta_{3} \mathrm{PREC}+\beta_{4} \mathrm{IL}+\beta_{5} \mathrm{BWS}+\varepsilon$ (1)

where NVWI is the net volume of virtual water import expressed in million $\mathrm{m}^{3}$, POP the size of the country's population in million, GDP the gross domestic product in million (constant 2005) US\$, IL the area of irrigated land in 1000 ha, PREC the precipitation during the (crop-specific) growing period in $\mathrm{mm}$, and BWS the blue water scarcity as a percentage. Parameter $\alpha$ is the constant in the regression, $\beta_{1}, \beta_{2}$, $\beta_{3}, \beta_{4}$ and $\beta_{5}$ are the coefficients to be estimated and $\varepsilon$ is the error term. The period of study is 1981-2010.

Assumptions for regression modeling such as normality of the distribution of variables, heteroscedasticity and collinearity are checked in order to ensure that the model meets these assumptions and to allow appropriate changes if needed. In the statistical hypothesis testing, we expect a number of linear dependencies to be significant. The main hypothesis is that water scarcity is an important variable in explaining NVWI. Per crop and variable, related hypotheses are as follows:

1. We expect POP, which shows an increasing trend during the period of study (World Bank, 2016; see Fig. S1a), to explain the trend in NVWI. Population growth is expected to drive consumption and thus have a positive impact on NVWI for all selected crops $(\beta 1>0)$, so population growth will boost NVWI.

2. We expect GDP, which also shows an increasing trend (World Bank, 2016; Fig. S1b), to explain the trend of NVWI. Increase of GDP is expected to drive consumption and will have a positive impact on NVWI $(\beta 2>0)$ for all crops.

3. Precipitation (PREC), which has a clear inter-annual variability for all crops during the period of study (Harris et al., 2014; Fig. S1c), is expected to drive agricultural production and therefore to have a negative impact on NVWI in case of crops that are predominantly rainfed $(\beta 3<0)$, so mainly wheat, barley and olives. It is expected that precipitation could explain a part of the inter-annual variability of the NVWI.

Table 2

Previous and current regression studies and their dependent and independent variables.

\begin{tabular}{|c|c|c|c|}
\hline Study & Type of study & Dependent variable & Independent variables \\
\hline Yang et al. (2003) & $\begin{array}{l}\text { Cross-country study for averages over two 5-year } \\
\text { periods }\end{array}$ & Net cereal import & $\begin{array}{l}\text { - Renewable fresh water per capita } \\
\text { - Sum of arable land and permanent crop land per } \\
\text { capita } \\
\text { - Irrigated land area per capita } \\
\text { - GDP per capita } \\
\text { - Annual fertilizer application rate per capita }\end{array}$ \\
\hline $\begin{array}{l}\text { Kumar and Singh } \\
\qquad(2005)^{\mathrm{a}}\end{array}$ & Cross-country analysis for one period of time & Virtual water trade & $\begin{array}{l}\text { - Renewable water availability per capita } \\
\text { - Agricultural water withdrawal per capita } \\
\text { - Net gross cultivated land } \\
\text { - Net gross irrigated land } \\
\text { - GDP per capita } \\
\text { - Human Development Index (HDI) }\end{array}$ \\
\hline $\begin{array}{l}\text { Yang and Zehnder } \\
\text { (2007) }\end{array}$ & Cross-country analysis for two averages of 10 years & $\begin{array}{l}\text { Food trade (cereal, oil, sugar, fruit and } \\
\text { vegetables) }\end{array}$ & $\begin{array}{l}\text { - Water resources availability per capita } \\
\text { - GDP per capita } \\
\text { - Irrigated area per capita }\end{array}$ \\
\hline Current study & $\begin{array}{l}\text { One country case study, annual analysis over } 30 \\
\text { years (1981-2010) }\end{array}$ & Net virtual water (NVWI) & $\begin{array}{l}\text { - Blue water scarcity (blue water footprint/renewable } \\
\text { water availability) } \\
\text { - Irrigated land } \\
\text { - GDP } \\
\text { - Population } \\
\text { - Precipitation }\end{array}$ \\
\hline
\end{tabular}

\footnotetext{
a In this study variables have been tested jointly and separately.
} 
4. Irrigated land (IL), which has inter-annual variability for wheat and barley and an increasing trend for the rest of crops during the period of study (Ministry of Agriculture, 1981-2010b; Fig. S1d), is expected to have a negative effect on NVWI. In case of irrigation land expansion, a country could produce more, therefore its imports will decline $(\beta 4<0)$. The negative impact is likely to be clearer for crops that are mainly irrigated, such as dates, tomatoes and potatoes. IL is expected to explain both trend and inter-annual variability of NVWI.

5. Blue water scarcity (BWS), which shows inter-annual variability and a slight trend during the study period (Fig. S1e), is expected to positively affect NVWI for all crops in years where BWS is relatively severe $(\beta 5>0)$. The higher BWS, the greater NVWI in a specific year is expected to be, to release pressure on the water resources.

The sources of the data needed to perform the regressions are summarized in Table 3. All data are available as a time series for the 30-year period 1981-2010.

\subsection{Estimating the water footprint of crop production and virtual water trade related to crop trade}

This study follows the terminology and methodology as set out in The Water Footprint Assessment Manual (Hoekstra et al., 2011), which contains the global standard for Water Footprint Assessment (WFA) developed by the Water Footprint Network. Annual green and blue water footprints (WF) related to the production of the selected crops in Tunisia during the period 1981-2010 were estimated on a yearly basis at grid-level with a spatial resolution of $5 \times 5$ arc minute. We did not include the grey WF in this study since we focus on analysing NVWI in relation to blue water scarcity, not water pollution. The selected crops account for $79 \%$ of the aggregated green and blue WF of crop production in Tunisia over the period $1996-2005$ and for $62 \%$ of the total blue WF (Chouchane et al., 2015). The export of olive oil, dates, wheat and tomatoes accounts for $72 \%$ of the total crop-related virtual water export (68\% for olive oil only) over the period 1996-2005 (Chouchane et al., 2015). The green and blue WFs per unit of crop $\left(\mathrm{m}^{3} / \mathrm{t}\right)$ were calculated by dividing green and blue crop water use ( $\mathrm{CWU}, \mathrm{m}^{3} / \mathrm{ha}$ ) by the crop yield (Y, tonne/ha) (Mekonnen and Hoekstra, 2011). CWU and Y were simulated per crop per grid per year at daily basis using the user interface and the plug-in of FAO's AquaCrop model version 4.0 (Steduto et al., 2009). The separation of green and blue evapotranspiration (ET) was carried out by tracking the green and blue water in daily soil water balances based on the contributions from rainfall and irrigation, respectively, following Chukalla et al. (2015) and Zhuo et al. (2016).

Before running AquaCrop, inputs on crop calendars, reference harvest indexes and maximum effective rooting depths were carefully selected from different sources in order to reflect Tunisian conditions (Table 4), because these are the parameters to which the simulated yield is most sensitive (Vanuytrecht et al., 2014). The selected crops except for olives and dates already have default crop files in AquaCrop. For the case of olives and dates, additional information on initial canopy cover, maximum canopy cover, canopy expansion, canopy decline and plant density was collected from several sources (Ministry of Agriculture, 2000; Ministry of Agriculture, 2007b; Carr, 2013).

Virtual water flows are calculated by multiplying the trade volume for each crop in tonne by its water footprint in $\mathrm{m}^{3}$ per tonne. Gross

Table 3

Overview of data used for the regression.

\begin{tabular}{ll}
\hline Input & Sources \\
\hline Net virtual water import & Own estimation (described in Section 2.2) \\
Gross domestic product & World Bank (2016) \\
Irrigated land & Ministry of Agriculture (1981-2010b) \\
Precipitation & CRU TS-3.20 (Harris et al., 2014) \\
Population & World Bank (2016) \\
Blue water availability & Ministry of Agriculture (1981-2010a) \\
\hline
\end{tabular}

virtual water import and export are defined as the amount of water virtually imported by or exported from a country through trade. Net virtual water import is calculated as the net result of gross virtual water import and gross virtual water export. Gross virtual water import is estimated based on crop trade data from Ministry of Agriculture (2011) and a trade-weighted global average of the WF of traded crops from (Mekonnen and Hoekstra, 2011). Gross virtual water export is estimated based on crop trade data from Ministry of Agriculture (2011) and the water footprints of crop production in Tunisia estimated in this study.

The estimation of CWU of growing crops using AquaCrop requires a number of input data, including daily precipitation, daily reference evapotranspiration $\left(\mathrm{ET}_{0}\right)$, and maximum and minimum daily temperature. These climatic data were collected with a spatial resolution of 30 $\times 30$ arc minute at daily basis from CRU TS-3.20 (Harris et al., 2014) and downscaled to $5 \times 5$ arc minute grid level assuming homogeneous climate per $30 \times 30$ arc minute grid cell. Soil properties at 5 $\times 5$ arc minute resolution were obtained from the ISRIC-WISE version 1.2 dataset (Batjes, 2012). Data on irrigated and rain-fed harvested area for each crop at $5 \times 5$ arc minute resolution were obtained from the MIRCA2000 dataset (Portmann et al., 2010). For the case of crops that are not available in this dataset (olives and dates) we use the 5 $\times 5$ arc minute map from Monfreda et al., 2008. We derive harvested area at $5 \times 5$ arc minute by applying scaling coefficients to the reference MIRCA2000 map to meet the values of the yearly harvested area at subnational level (planted area in case of wheat and barley) from the dataset collected from the Ministry of Agriculture (1981-2010a). The scaling factor for each sub-national level is applied to all grids within that region. The yearly percentages of rain-fed and irrigated areas specific per crop were obtained from the Ministry of Agriculture (1981-2010a). Since no information about the initial soil moisture in the year 1981 is available, we first run the model for the whole period with an initial soil moisture at field capacity and then assume the average of the soil moisture values for the years 1982-2010 (from the output of AquaCrop) as the initial soil moisture in the year 1981. The results of a second run for the whole period, initialised in 1981 with this derived average soil moisture, are used for the calculation of CWU. Due to lack of data, in calculating CWU using AquaCrop, a few assumptions were made. First, soil water salinity was not taken into account. Second, we do not account for capillary rise of groundwater assuming that groundwater in Tunisia is too deep to get close to the crops root zone. Third, we assume that there is default field management. Finally, for the tree crops (olives and dates), we assume that we are simulating mature trees, simulating the canopy cover from the date that the tree gets new leaves until the maximum canopy cover and harvesting.

\section{Results}

\subsection{Water footprint of crops}

The average annual aggregated green and blue water footprint for the selected crops in Tunisia over the period 1981-2010 was 14 billion $\mathrm{m}^{3} /$ year (Table 5 ). The total WF is dominated by the green component, which contributes $80 \%$ to $90 \%$ of the total, and $85 \%$ on average. The water footprint is largest in the north of the country (Fig. 1), where mainly wheat and barley are grown, while the largest share of blue WF in the total WF is found in the centre and south of the country, where olives and dates are mostly grown. Among the selected crops, olives had the largest WF per unit of weight $\left(\mathrm{m}^{3} / \mathrm{t}\right)$, while tomatoes and potatoes had the smallest WF. In terms of the blue WF per tonne, dates had the largest, while potatoes had the smallest value. Regarding the green WF per tonne, olives, barley and wheat had the largest values.

For the selected crops, olives have the largest share in the total WF in terms of $\mathrm{m}^{3} /$ year, followed by wheat and barley, while potatoes and dates had the smallest share. In terms of blue WF, wheat have the 
Table 4

Crop characteristics.

\begin{tabular}{|c|c|c|c|c|c|c|c|}
\hline \multirow[t]{2}{*}{ Crop } & \multirow[t]{2}{*}{ Planting date } & \multicolumn{4}{|c|}{ Crop growing stages } & \multirow[t]{2}{*}{ Reference harvest index $\left(\mathrm{HI}_{0}\right)$} & \multirow[t]{2}{*}{ Max. rooting depth $(\mathrm{m})$} \\
\hline & & Init. & Dev. & Mid & Late & & \\
\hline Wheat & 15th November & 30 & 140 & 40 & 30 & $34 \%$ & 1.5 \\
\hline Barley & 15th November & 30 & 60 & 60 & 40 & $34 \%$ & 1.3 \\
\hline Potatoes & 31st January & 25 & 30 & 35 & 30 & $75 \%$ & 1.5 \\
\hline Olives & 1st March & 30 & 90 & 60 & 90 & $10 \%$ & 2.5 \\
\hline Dates & 15st March & 10 & 110 & 170 & 365 & $20 \%$ & 4 \\
\hline Tomatoes & 15th March & 30 & 40 & 45 & 30 & $63 \%$ & 1 \\
\hline
\end{tabular}

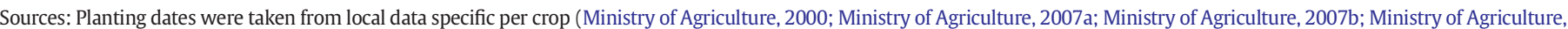

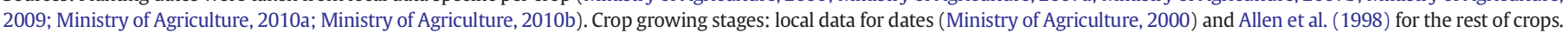

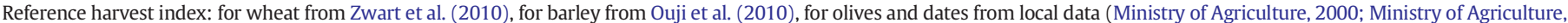

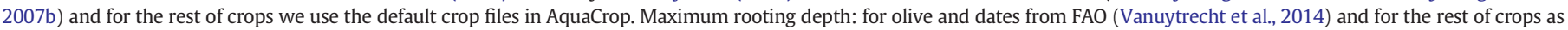
calibrated in AquaCrop.

largest share, followed by dates, olives and barley. In terms of green WF, olives have the largest share, followed by wheat and barley (Fig. 2).

The annual variability of WFs related to the production of the selected crops in Tunisia is presented in Fig. 3. The green WF contributes most to the total WF and its inter-annual variability. The fluctuation in the total WF is driven by inter-annual climatic variability, and in particular by the length of the cropping season, constrained by precipitation.

The annual green, blue and total WF per unit of weight is shown in Fig. 4 for all crops. Water footprints are dominated by the green WF, except for dates and tomatoes where the total WF is dominated by the blue fraction. Tomatoes have the strongest decrease in their WF per tonne during the study period, which can be explained by the increase of tomato yields.

\subsection{Virtual water trade}

The annual net virtual water trade related to trade in the six selected crops of crop products is shown in Fig. 5. All six show a trend over time: net virtual water imports related to staples crops (wheat, barley and potatoes) are increasing, while net virtual water exports related to cash crops (olive oil, dates and tomatoes) are increasing as well. Dates show the greatest change over the study period. Furthermore, it is shown that virtual water trade related to the three staples crops and olive oil has a high inter-annual variability.

\subsection{Regression results}

We find high collinearity between two pairs of independent variables, namely (POP, GDP) and (PREC, IL), forcing us to make a choice for variables per pair to perform a meaningful regression. From the statistically allowed combinations we selected two models. The models contain at least one variable hypothesized to explain the trend in NVWI and one variable hypothesized to explain its inter-annual variability. We consider the two models for which the variable combinations provided the best regression performance for all crops (in terms

Table 5

The average green, blue and total water footprint of the selected crops in Tunisia. Period: 1981-2010.

\begin{tabular}{|c|c|c|c|c|c|c|}
\hline \multirow[t]{2}{*}{ Crop } & \multicolumn{3}{|c|}{$\begin{array}{l}\text { Water footprint per tonne of } \\
\text { crop }\left(\mathrm{m}^{3} / \text { tonne }\right)\end{array}$} & \multicolumn{3}{|c|}{$\begin{array}{l}\text { Total water footprint (million } \\
\mathrm{m}^{3} / \text { year) }\end{array}$} \\
\hline & Green & Blue & Total & Green & Blue & Total \\
\hline Wheat & 4100 & 550 & 4700 & 4600 & 610 & 5200 \\
\hline Barley & 5700 & 660 & 6400 & 2200 & 260 & 2500 \\
\hline Potatoes & 220 & 120 & 350 & 56 & 31 & 88 \\
\hline Olives & 7100 & 420 & 7500 & 5200 & 300 & 5500 \\
\hline Dates & 650 & 5000 & 5600 & 62 & 470 & 540 \\
\hline Tomatoes & 140 & 180 & 320 & 98 & 120 & 220 \\
\hline Total $^{\mathrm{a}}$ & & & & 12,000 & 1800 & 14,000 \\
\hline
\end{tabular}

a Total of the selected crops only. of better fit and higher $R^{2}$, which is a statistical measure of how close the data are to the fitted regression line):

Model I:

$\mathrm{NVWI}=\alpha+\beta_{1} \mathrm{POP}+\beta_{2} \mathrm{PREC}+\varepsilon$

Model II:

$\mathrm{NVWI}=\alpha+\beta_{1} \mathrm{GDP}+\beta_{2}$ BWS $+\beta_{3} \mathrm{IL}+\varepsilon$

The regression results for both models are shown in Table 6 .

NVWI for the rain-fed and mainly imported staple crops (wheat and barley) correlates to population and precipitation (model I) and to GDP and irrigated area (model II). Both models are plausible (in the sense that they can be explained). Increase in population requires more import of staple crops (positive correlation in the first model). The first model suggests that if the population increases with one million, Tunisia will need an extra NVWI of $400 \mathrm{Mm}^{3}$ of wheat and an extra NVWI of $170 \mathrm{Mm}^{3}$ of barley. The fact that precipitation is negatively correlated with NVWI for wheat and barley can be explained by considering that high precipitation in a certain year increases domestic production which leads to a decrease in the need for import. The first model suggests that every increase by $1 \mathrm{~mm}$ of precipitation within the crop growing period will decrease the yearly average NVWI of wheat and barley by 3.7 and $1.8 \mathrm{Mm}^{3}$, respectively. Both precipitation and population have a larger impact on NVWI of wheat than on NVWI of barley.

In the second model, irrigated land negatively correlates with NVWI for wheat and barley, which can be explained by considering that more irrigated land increases domestic production and decreases the need for import. According to the model, an increase in irrigated land by 1000 ha will reduce the yearly average NVWI of both wheat and barley by $16 \mathrm{Mm}^{3}$. The positive correlation between GDP and NVWI can be explained by assuming that increased GDP translates in greater demand and thus more import. The second model suggests that increasing the GDP by 1 million will decrease the yearly average NVWI of wheat and barley by 0.05 and $0.01 \mathrm{Mm}^{3}$, respectively.

NVWI for potatoes is partially $\left(R^{2}=16 \%\right)$ explained by model I (population and precipitation). The significance of population for the case of potatoes can be explained the same way as for wheat and barley. However, a one million increase in population will decrease the NVWI of potatoes by $1.55 \mathrm{Mm}^{3}$, which is a much smaller effect than in the cases of wheat and barley. This is due to the fact that import volumes of wheat and barley are much larger than for potatoes. Precipitation is not significant for the case of potatoes, which can be explained by the fact that potatoes are mainly irrigated crops. Model II does not show significant regression results for potatoes.

For dates, both models I and II give a statistically strong correlation, with $R^{2}$ of 68 and $88 \%$ respectively, which means that $68 \%$ of the dynamics in NVWI of dates can be explained by the combination of population and precipitation, and $88 \%$ by the combination of GDP, irrigated land, 

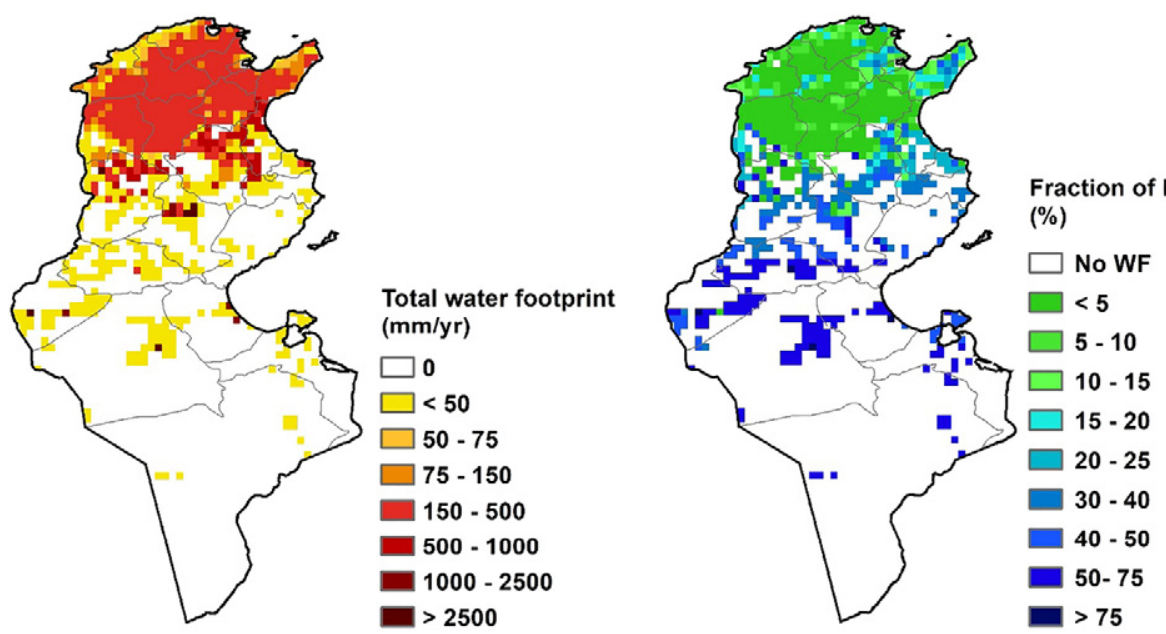

Fig. 1. Annual variability of green, blue and total WF for the production of the selected crops in Tunisia. Period: 1981-2010.

and blue water scarcity. However, only model II is plausible, with GDP and irrigated area significantly negatively correlated to dynamics in NVWI (i.e. GDP and irrigated area are positively correlated to net virtual water export). More irrigated land means more production and thus more export. In model II, an increase in irrigated land by 1000 ha increases the net virtual water export of dates by $5.6 \mathrm{Mm}^{3}$. Explaining the negative correlation between NVWI and GDP is ambiguous; greater GDP could be the driver of investments and production capacity and thus more export, or the greater GDP could be a result of the greater export. We find a negative correlation between GDP and NVWI (i.e. a positive correlation between GDP and export), but in terms of explanation one could also find a logic for a reverse relation: greater GDP could imply greater domestic consumption and thus reduced export. However, even though statistically significant, Model I doesn't have a real meaning for dates, because the negative sign found for population (representing a positive correlation between population growth and export) is against our first hypothesis and doesn't have a clear explanation; most likely, both population and export of dates have happened to grow in the study period, giving a positive correlation, but without causal relation.

For olives and tomatoes, both models give statistically significant correlations, but none of the models seem plausible in the sense of really explaining something. As in the case of dates, the negative correlation between NVWI and population (positive correlation between export and population) probably reflects the coincidence of two similar trends without causal relation. The negative correlation between NVWI and GDP (positive correlation between export and GDP) could refer to increased exports through increased investments (possible through the higher GDP) or to increased GDP through increased exports. However, one could also argue that higher GDP would go together with higher domestic consumption and thus less olives and tomatoes left for export.

The blue water scarcity variable is found not to be statistically significant in explaining the dynamics in NVWI of any of the six selected crops. Blue water scarcity is only found to have a small positive correlation with NVWI for the case of dates (higher BWS correlated to smaller virtual water export). This can be explained by the high dependence of dates production on blue water. But in combination with other variables, blue water scarcity is found not to be significantly influencing NVWI of dates.

Using the two models for dates and wheat, Fig. 6 shows the annual predicted and actual NVWI for these two crops over time. We see that for the case of dates, both models I and II predict the trend in NVWI better than the inter-annual variability. For the case of wheat, both models capture both trend and inter-annual variability in NVWI.
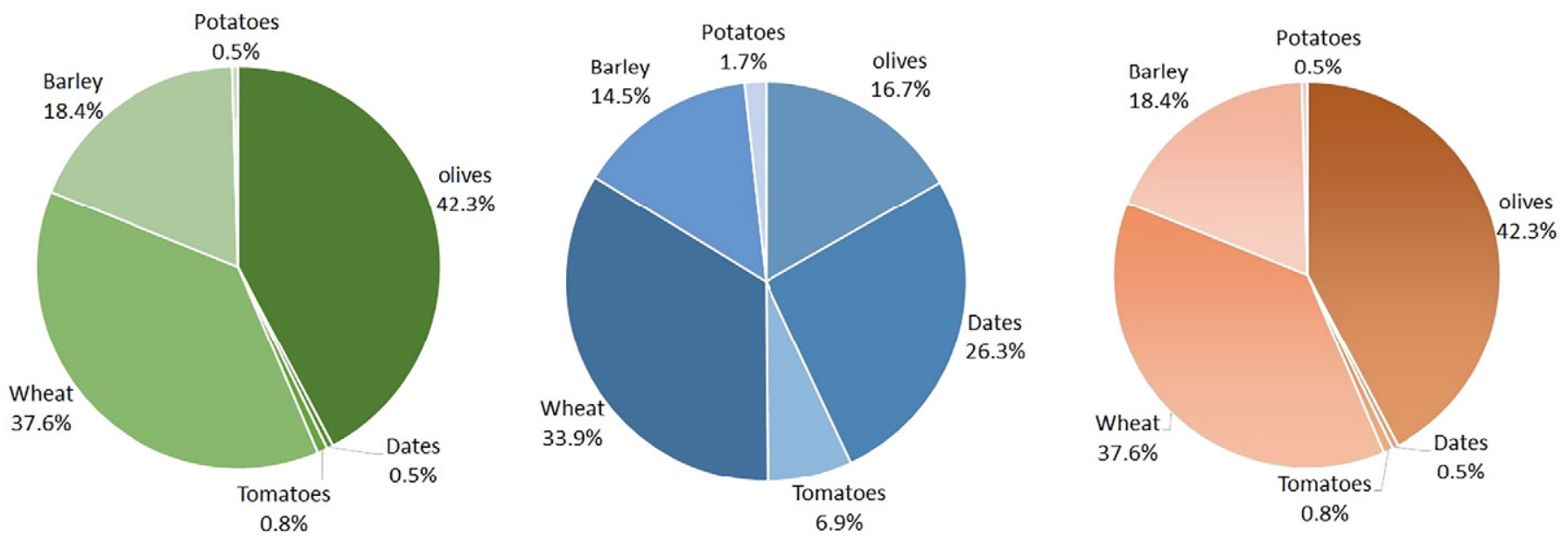

Fig. 2. The annual green, blue and total water footprint per tonne of crop for the selected crops in Tunisia for the period 1981-2010. 


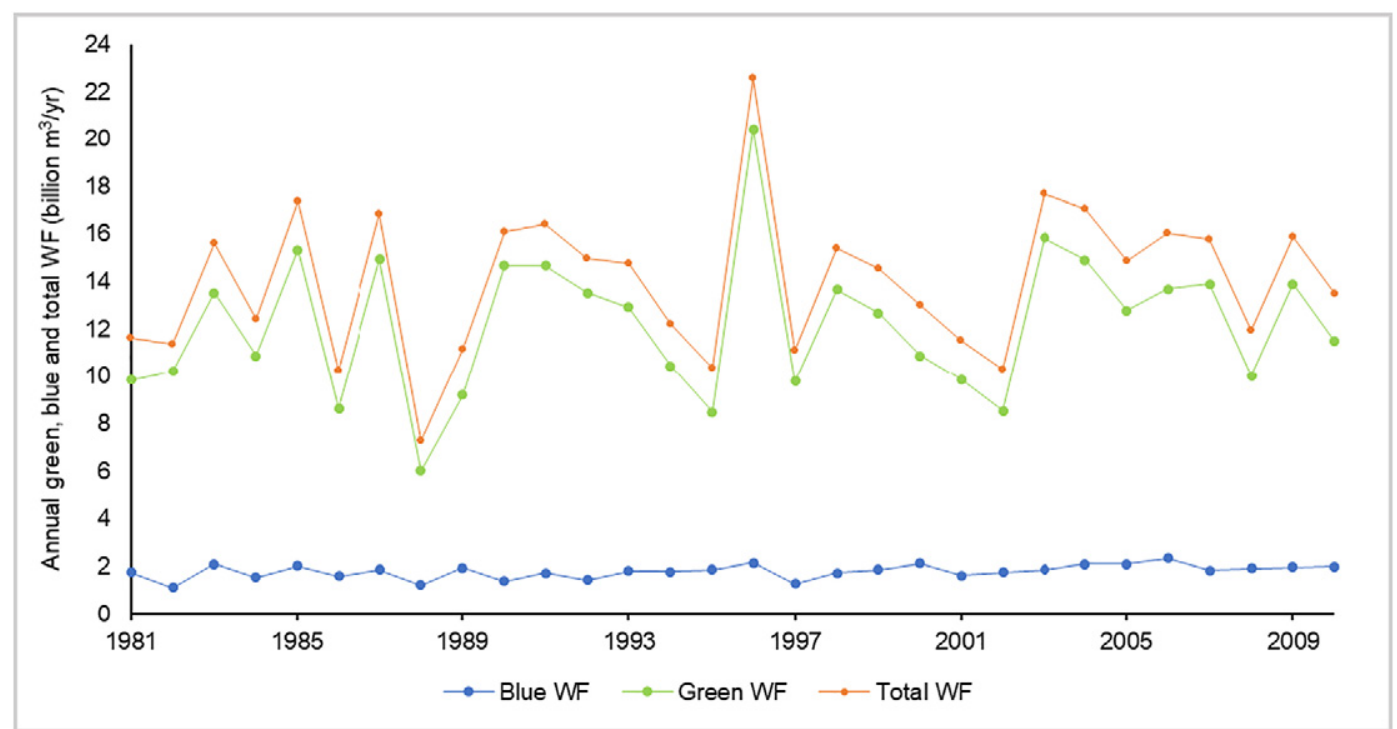

Fig. 3. Annual net virtual water import related to trade in wheat, barley, potatoes, olive oil, dates and tomatoes (1981-2010).

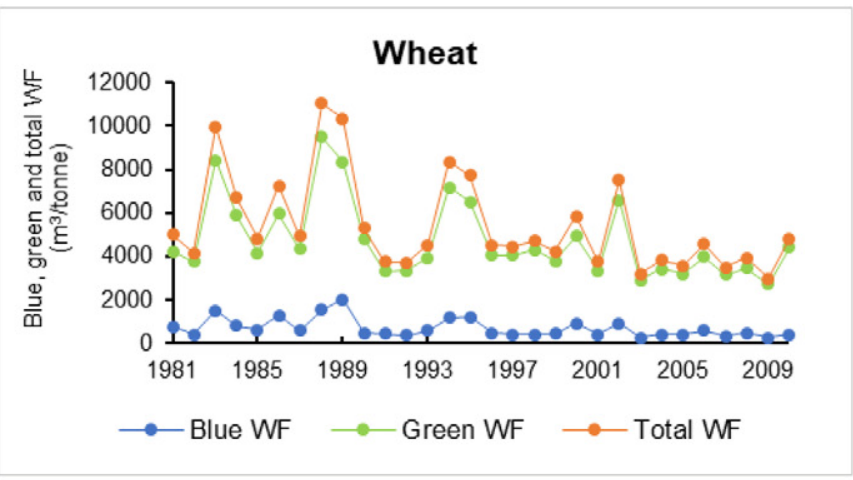

\section{Potatoes}
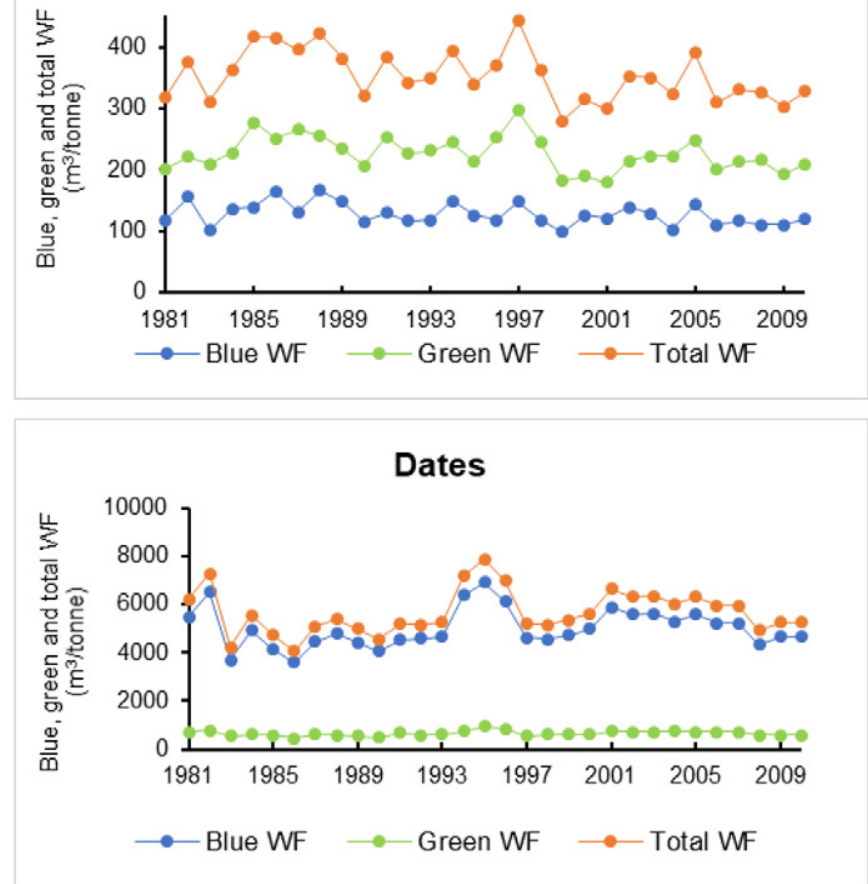
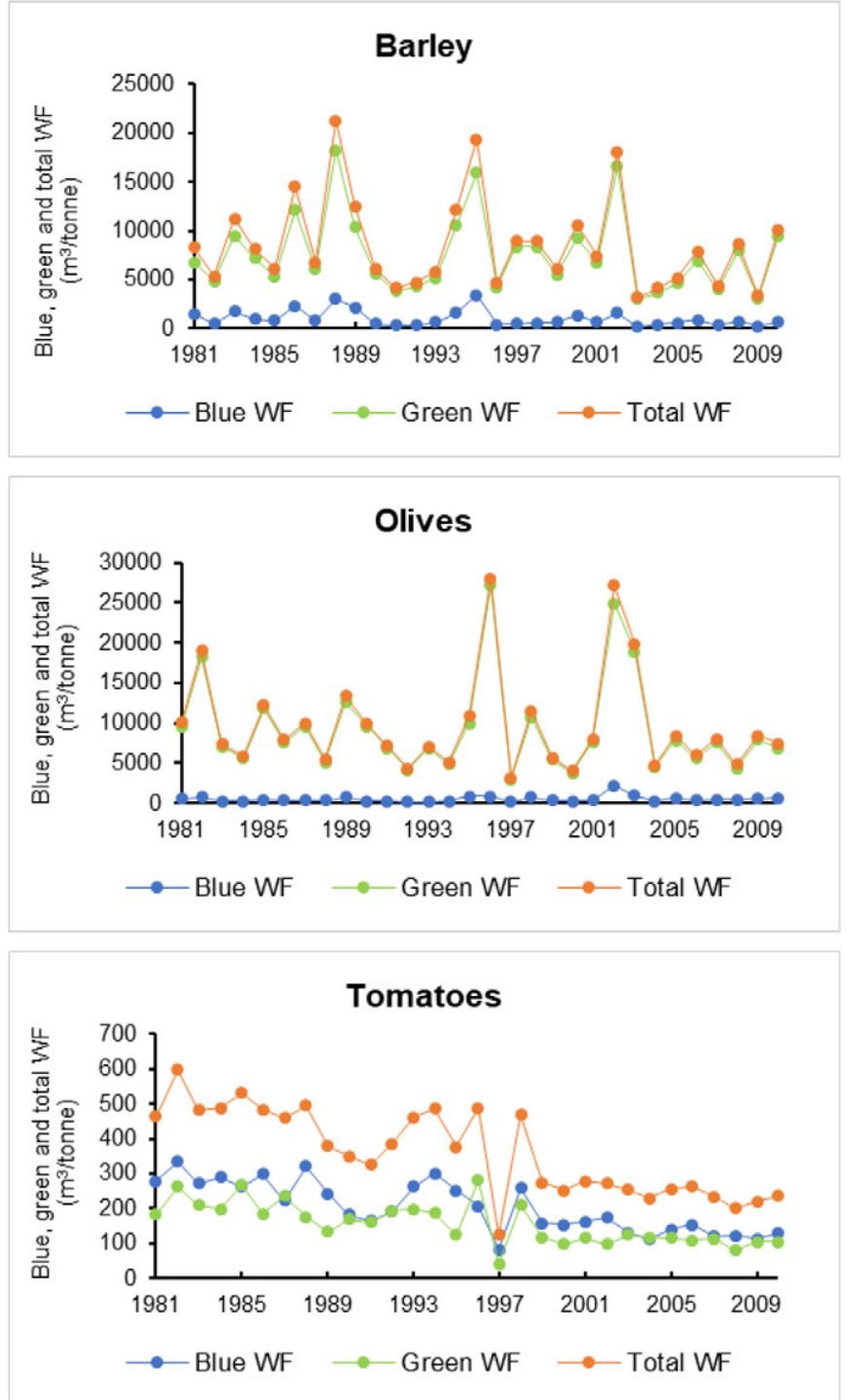

Fig. 4. Actual versus predicted net virtual water import of wheat and dates. 

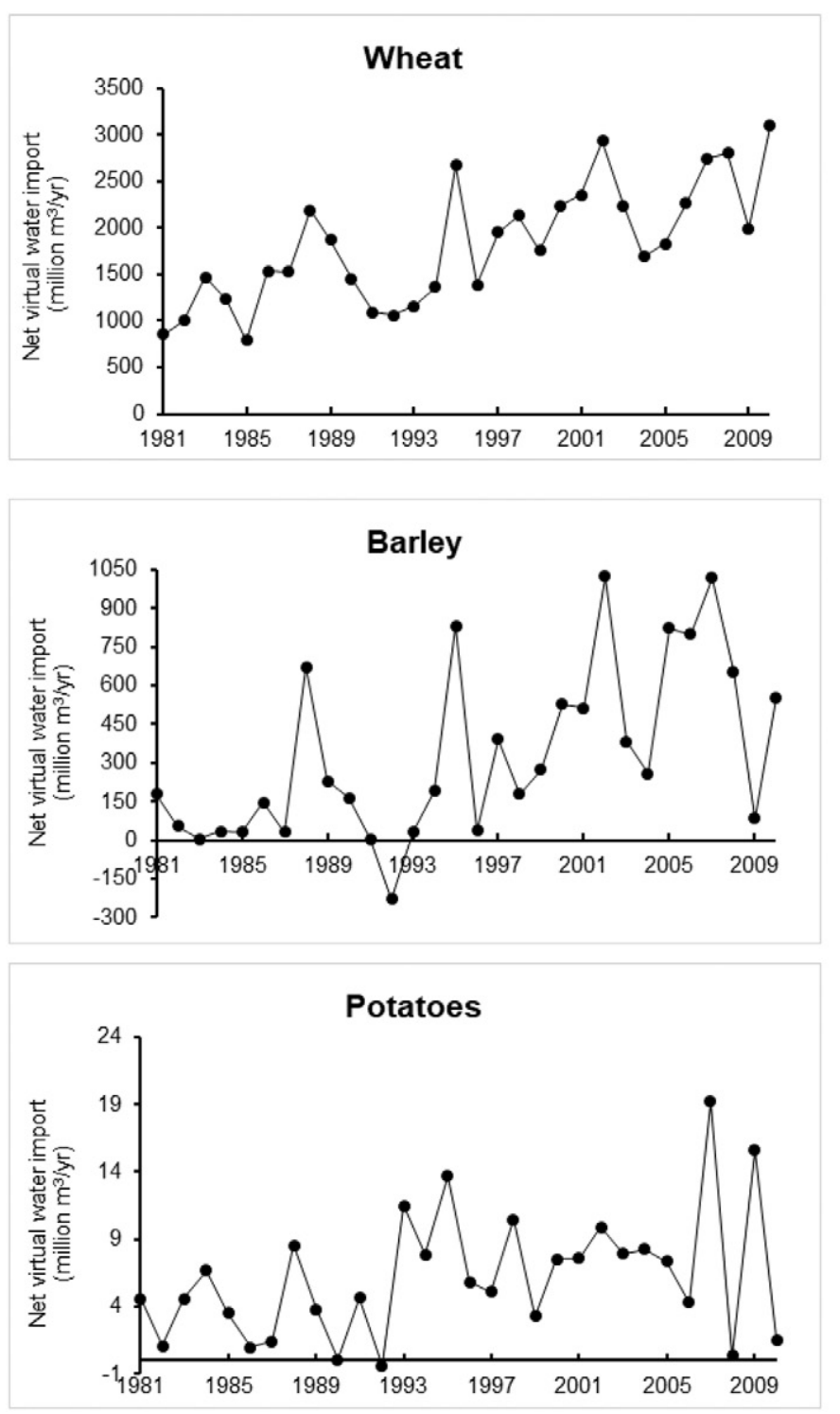
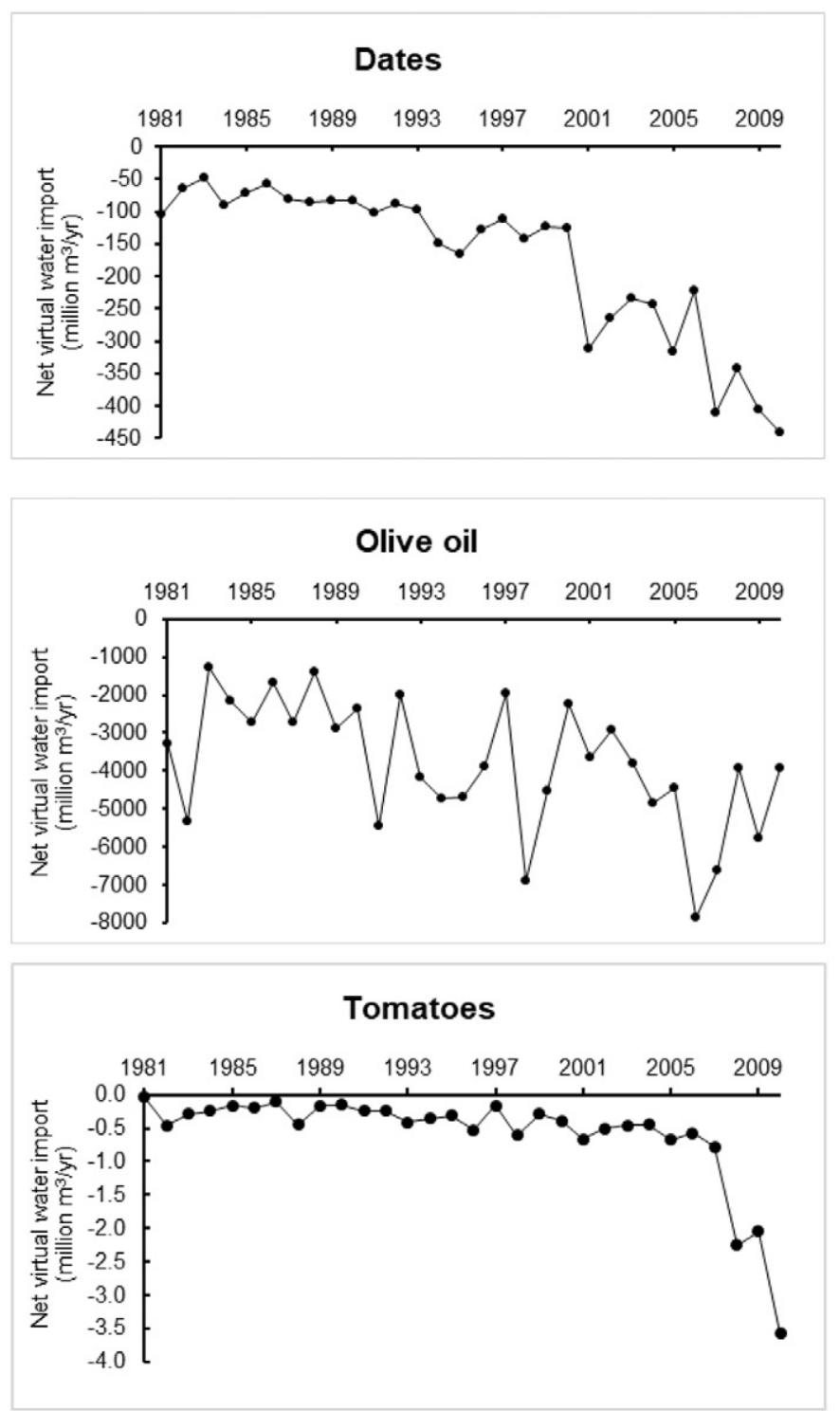

Fig. 5. Annual net virtual water import related to trade in wheat, barley, potatoes, olive oil, dates and tomatoes (1981-2010).

\section{Discussion}

The current study assessed the green and blue WF of the selected crops in Tunisia. A comparison of the average values for the period 1996-2005 from the current study and reported values in Mekonnen and Hoekstra (2011) is presented in Table 7. Except for olives, the values for total (green plus blue) WF from the current study are higher than those from the previous study. Especially for tomatoes, wheat and barley current values are higher by approximately 60, 40 and 35\% respectively. Particularly the differences in blue WF are relatively large: the current study gives about 6 times higher values for wheat and barley and 3 times higher for tomatoes. A few methodological differences could explain the different results of the two studies. First, the current study makes use of AquaCrop instead of CropWat for computing CWU, representing water stress on crop yield more accurately. Second, planted area was used for wheat and barley instead of harvested area as in the earlier study. The current study accounts for water use in areas on which cereals are planted but not harvested due to droughtinduced yield losses, thus also accounting for unproductive water use. Finally, we use local data to scale harvested/planted area of the reference maps from Portmann et al. (2010) and Monfreda et al. (2008) while in the previous study FAO's dataset was used. Additionally, we scale at sub-national level instead of scaling to country level which is an improvement comparing to the previous study. All methodological differences suggest the current estimates to be more accurate. For olives, the total WF per tonne in the current study was lower than in the previous study, but the blue WF was higher.

The finding that GDP, population and irrigated land are significant in explaining NVWI dynamics supports the results of Tamea et al. (2014), who studied the drivers of virtual water trade based on gravity laws. Their finding supports also the positive correlation between GDP and virtual water import and export. However, the distance between countries is not included in our study, since we are looking into explaining virtual water trade dynamics of one water-scarce country in relation to its internal factors.

The finding that blue water scarcity was not an influencing factor of virtual water trade in a water-scarce country is similar to the finding of Kumar and Singh (2005) and Fracasso et al. (2016), who found that water endowment and water scarcity level were not driving factors for virtual water trade.

The first hypothesis formulated at the start of this study (Section 2.1), on the positive correlation between population and 
Table 6

Summary of regression results and statistical tests for models I and II.

\begin{tabular}{|c|c|c|c|}
\hline Model I & Coefficient & Model II ${ }^{5}$ & Coefficient \\
\hline Wheat & & Wheat & \\
\hline Population & $400^{* * *}(8.0)^{\mathrm{a}}[1.0]^{\mathrm{b}}$ & GDP & $0.05^{* * *}(5.7)[1.5]$ \\
\hline Precipitation & $-3.7^{* * *}(-4.9)[1.0]$ & $\begin{array}{l}\text { Blue water } \\
\text { scarcity }\end{array}$ & $440(0.6)[1.6]$ \\
\hline Constant & $-640(-1.3)$ & Irrigated land & $-16^{* * *}(5.0)[1.3]$ \\
\hline$R^{2}$ & 0.76 & Constant & $1600(4.4)$ \\
\hline F-statistic & $42^{* * * *}$ & $R^{2}$ & 0.78 \\
\hline Breusch-Pagan ${ }^{\mathrm{C}}$ & 0.71 & F-statistic & $30^{* * *}$ \\
\hline \multirow[t]{2}{*}{ Durbin-Watson $^{\mathrm{d}}$} & 1.53 & Breusch-Pagan & 0.74 \\
\hline & & Durbin-Watson & 1.62 \\
\hline Barley & & Barley & \\
\hline Population & $170^{* * *}(4.5)[1.0]$ & GDP & $0.01 *(1.9)[1.7]$ \\
\hline Precipitation & $-1.8^{* * *}(-3.2)[1.0]$ & $\begin{array}{l}\text { Blue water } \\
\text { scarcity }\end{array}$ & $770(1.2)[1.7]$ \\
\hline Constant & $-620(-1.7)$ & Irrigated land & $-16^{* * *}(-3.8)[1.5]$ \\
\hline$R^{2}$ & 0.52 & Constant & $130(0.5)$ \\
\hline F-statistic & $15^{* * *}$ & $R^{2}$ & 0.58 \\
\hline Breusch-Pagan & 0.08 & F-statistic & $12^{* * * *}$ \\
\hline \multirow[t]{2}{*}{ Durbin-Watson } & 1.63 & Breusch-Pagan & 0.07 \\
\hline & & Durbin-Watson & 1.76 \\
\hline Potatoes & & Potatoes & \\
\hline Population & $1.55^{* *}(2.3)[1.0]$ & GDP & $0.001^{*}(2.0)[1.0]$ \\
\hline Precipitation & $-0.01(-0.5)[1.0]$ & Constant & $1.91(0.8)$ \\
\hline Constant & $-5.9(-0.9)$ & $R^{2}$ & 0.12 \\
\hline$R^{2}$ & 0.16 & F-statistic & $3.9^{*}$ \\
\hline F-statistic & $2.6^{*}$ & Breusch-Pagan & 0.09 \\
\hline Breusch-Pagan & 0.82 & Durbin-Watson & 2.29 \\
\hline Durbin-Watson & 2.18 & & \\
\hline Dates & & Dates & \\
\hline Population & $-79^{* * *}(-7.5)[1.0]$ & GDP & $-0.01^{*}(-2.0)[1.5]$ \\
\hline Precipitation & $0.10(0.5)[1.0]$ & $\begin{array}{l}\text { Blue water } \\
\text { scarcity }\end{array}$ & $160(1.5)[1.3]$ \\
\hline Constant & $510^{* * *}(5.2)$ & Irrigated land & $-5.6^{*}(-1.7)[1.6]$ \\
\hline$R^{2}$ & 0.68 & Constant & $75(1.6)$ \\
\hline F-statistic & $28^{* * * *}$ & $R^{2}$ & 0.88 \\
\hline Breusch-Pagan & 0.18 & F-statistic & $65^{* * *}$ \\
\hline \multirow[t]{2}{*}{ Durbin-Watson } & 1.83 & Breusch-Pagan & 0.23 \\
\hline & & Durbin-Watson & 1.97 \\
\hline Olives oil & & Olives oil & \\
\hline Population & $\begin{array}{l}-680^{* * *}(-2.9) \\
{[1.0]}\end{array}$ & GDP & $\begin{array}{l}-0.10^{* *}(-2.3) \\
{[1.3]}\end{array}$ \\
\hline Precipitation & $-1.20(-0.3)[1.0]$ & $\begin{array}{l}\text { Blue water } \\
\text { scarcity }\end{array}$ & $-3800(-1.1)[1.3]$ \\
\hline Constant & $2500(1.1)$ & Constant & $-150(-0.1)$ \\
\hline$R^{2}$ & 0.25 & $R^{2}$ & 0.29 \\
\hline F-statistic & $4.5^{* *}$ & F-statistic & $5.6^{* * *}$ \\
\hline Breusch-Pagan & 0.50 & Breusch-Pagan & 0.77 \\
\hline Durbin-Watson & 2.05 & Durbin-Watson & 2.14 \\
\hline Tomatoes & & Tomatoes & \\
\hline Population & $\begin{array}{l}-0.40^{* * *}(-3.7) \\
{[1.0]}\end{array}$ & GDP & $\begin{array}{l}-5.0^{* * *}(-3.8) \\
{[1.9]}\end{array}$ \\
\hline Precipitation & $0.002(0.5)[1.0]$ & $\begin{array}{l}\text { Blue water } \\
\text { scarcity }\end{array}$ & $1.5(1.2)[1.3]$ \\
\hline Constant & $2.4^{* *}(2.55)$ & Irrigated land & $-0.04(-1.3)[1.8]$ \\
\hline$R^{2}$ & 0.34 & Constant & $1.0(1.3)$ \\
\hline F-statistic & $7.0^{* * *}$ & $R^{2}$ & 0.58 \\
\hline Breusch-Pagan & 0.71 & F-statistic & $11^{* * * *}$ \\
\hline \multirow[t]{2}{*}{ Durbin-Watson } & 1.58 & Breusch-Pagan & 0.45 \\
\hline & & Durbin-Watson & 1.68 \\
\hline
\end{tabular}

***,** and * denote statistical significance at 99\%, 95\% and 90\% confidence levels. The overall significance of $F$-static reject the null-hypothesis and conclude that the model provides a better fit than the intercept-only model.

a The $t$-values, which are the values of the $t$-statistic for testing whether the corresponding regression coefficient is different from 0 , are given between parentheses.

b The variance inflation factor (VIF), shown between square brackets, is used for detecting multicollinearity, all VIF are $<3$ implying that multicollinearity is not an issue.

c The homoscedasticity is tested by the means of Breusch-Pagan test, all p-values are higher than 0.05 implying the rejection of the null hypothesis of homoscedasticity.

$\mathrm{d}$ The serial correlation is tested by the means of Durbin Watson static. All values are within $t$ between the two critical values of $1.5<\mathrm{d}<2.5$ (rule of thumb). Therefore, we can assume that there is no first order linear auto-correlation in our multiple linear regression data ${ }^{5}$ The variable IL was excluded from Model II for olive oil and potatoes due to the fact that it showed high collinearity with GDP for these two crops while the variable BWS was excluded from model II for potatoes due to high collinearity with IL.
NVWI, holds for the imported staple crops (wheat, barley and potato), but not for the exported cash crops (dates, olive oil and tomato). The second hypothesis, about GDP, is confirmed by model II for the staple crops again, not for the cash crops. Regarding the third hypothesis about the role of precipitation, the results were as expected for wheat and barley, which are rain-fed staple crops, thus sensitive to rainfall in the country. For olives, mainly rain-fed and an exported crop, precipitation was not found to be significant in explaining the dynamics in net virtual water export. Furthermore, precipitation was not significant for crops that are mainly irrigated (dates and tomatoes), which was expected. Regarding the fourth hypothesis, irrigated land has been significant for wheat, barley and dates. This was not expected for wheat and barley, because we expected an impact of irrigated land on mainly irrigated crops. Finally, the fifth hypothesis about the relevance of blue water scarcity, fails for all selected crops.

Dates and olives, the most exported crops in Tunisia, have the highest total WF per unit among the selected crops. Dates have the highest blue water footprint in $\mathrm{m}^{3} /$ tonne. Additionally, dates are only produced in the south of Tunisia, the region with the highest scarcity level (Chouchane et al., 2015). A remaining question is why a waterscarce country continues producing a blue water intensive crop like dates for export. The selected variables of this study couldn't answer this question; other factors must be the reason. Dates have also a low economic water productivity and from an economic perspective reallocating the water used by dates for growing other crops, with higher water productivity, such as potatoes and tomatoes would be more beneficial (Chouchane et al., 2015).

The current study has a number of limitations that are mostly due to a lack of data. First, in calculating blue water scarcity we use the data on water resources availability from the Tunisian Ministry of Agriculture, which reports the volume of fresh water that is operationally available for use in each year. This measure does not subtract environmental flow requirements, which would be better to get a more appropriate measure for sustainable water availability (Hoekstra et al., 2012). Second, we use precipitation as proxy for green water availability instead of using the soil moisture (rainwater stored in soil) that is a better measure of green water availability. Third, the list of independent variables used in analysing the dynamics in net virtual water import is limited to socio-economic and water-balance-related factors. However, there are other factors that could influence the virtual water trade in a country that are not included in current study, such as: agricultural policies, value of water, international prices, etc. Fourth, the difference between harvested and planted area per crop could only be included for grid cells where a harvested area for that crop existed around the year 2000 according to the databases used (Monfreda et al., 2008; Portmann et al., 2010). Finally, the estimation of WF was limited to the green and blue $W F$, excluding the grey WF, mainly because of the absence of good data on fertilizer application rates. We assumed no stress related to fertilizer application in calculating the green and blue WFs using AquaCrop.

\section{Conclusion}

In general, the regression exercise has been successful in explaining net virtual water import of staple crops (wheat, barley, potatoes) and less or not at all in explaining net virtual water export of cash crops (dates, olives, tomatoes).

The dynamics of NVWI into Tunisia from 1980 to 2010 for the staple crops wheat and barley can be explained with statistical significance by two different models, one using precipitation and population as explaining variables (model I), and the other using GDP and irrigated land (model II). The models best explained long term trends as well as inter-annual variability for imported staple crops (mainly wheat and barley). For the case of potatoes, only population was found to be significant in explaining NVWI. The increase of population leads to an increasing demand of staple crops and therefore for more import. 

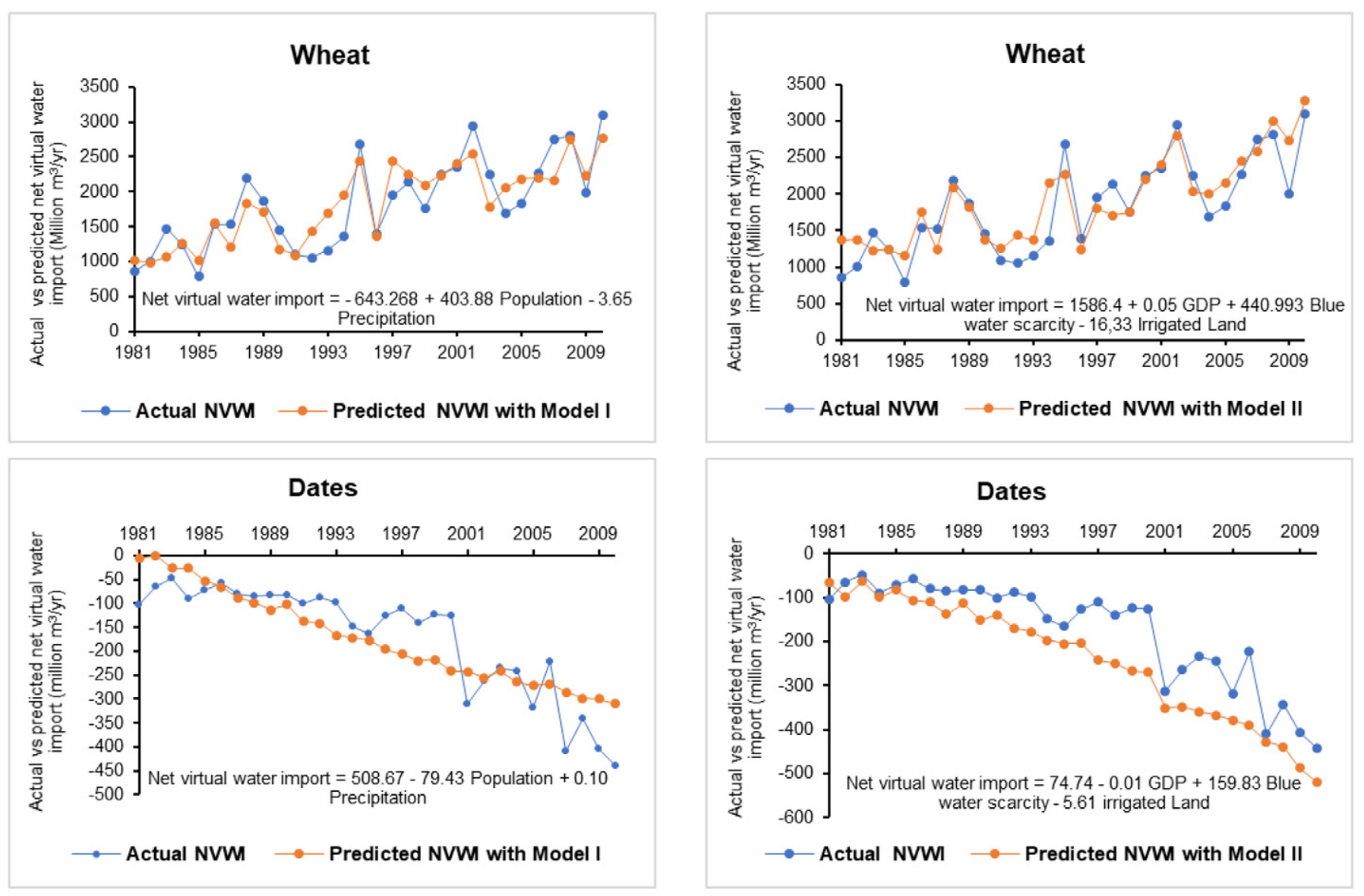

Fig. 6. Actual versus predicted net virtual water import of wheat and dates.

For dates, both models I and II give statistically strong correlation with dynamics in NVWI, however only model II is plausible, with irrigated land driving virtual water export. For olives and tomatoes, both models give a significant correlation but do not provide a plausible explanation of NVWI. The relation between GDP and NVWI can go two ways if we think about it (larger GDP thus larger domestic consumption and less export possibility, or larger GDP thus greater investments in domestic agriculture and thus greater export).

Regression models are able to significantly explain both trends and inter-annual variability for rain-fed crops (using model I). For irrigated crops, model II performs better and is able to explain trends significantly; no significant relation is found however with variables hypothesized to represent inter-annual variability.

Blue water scarcity did not appear as a significant factor in explaining NVWI of the selected crops in Tunisia. A water-scarce country as Tunisia may benefit from importing particularly water-intensive

Table 7

Comparison between estimated green and blue water footprint of the selected crops in Tunisia in the current and a previous study. Period: 1996-2005.

\begin{tabular}{|c|c|c|c|c|c|c|}
\hline \multirow[t]{2}{*}{ Crop } & \multicolumn{3}{|c|}{$\begin{array}{l}\left.\text { WF ( } \mathrm{m}^{3} / \text { tonne }\right) \text { estimated in } \\
\text { current study }\end{array}$} & \multicolumn{3}{|c|}{$\begin{array}{l}\text { WF }\left(\mathrm{m}^{3} / \text { tonne }\right) \text { from } \\
\text { Mekonnen and Hoekstra } \\
(2011)\end{array}$} \\
\hline & Green & Blue & Total & Green & Blue & Total \\
\hline Wheat & 3800 & 440 & 4200 & 2400 & 70 & 2500 \\
\hline Barley & 5200 & 490 & 5700 & 3600 & 80 & 3600 \\
\hline Potatoes & 220 & 120 & 350 & 110 & 120 & 230 \\
\hline Dates & 690 & 5300 & 6000 & 1000 & 3300 & 4300 \\
\hline Olives & 7200 & 440 & 7600 & 8800 & 330 & 9100 \\
\hline Tomatoes & 130 & 160 & 290 & 60 & 50 & 110 \\
\hline
\end{tabular}

staple crops instead of producing them domestically in order to reduce the pressure on local water availability and reduce blue water scarcity. However, this does not turn out to be the case for Tunisia during the period of study. Indirectly, blue water scarcity may have influenced the temporal development of irrigated area that was identified as a significant factor to explain net virtual water import for some crops.

In the period 2010-2050, population in Tunisia is projected to increase by $27 \%$ according to the UN medium projection scenario (Melorose et al., 2015), while climate change is expected to bring more inter-annual variability to the precipitation and a decline of about 20\% in the annual amount (Mitchell et al., 2004). Based on the role of population and precipitation in explaining NVWI of staple crops, this will have a big impact on the NVWI related to wheat and barley, which represent a big share of the Tunisian diet.

In future studies, other factors could be taken into account, especially for exported crops, such as the price and value added. Furthermore, future research could be done to develop projections of future NVWI based on population growth and climate change scenarios.

\section{Acknowledgment}

The present work was (partially) developed within the frame-work of the Panta Rhei Research Initiative of the International Association of Hydrological Sciences (IAHS). We thank the reviewers of an earlier version of this manuscript for their constructive comments.

\section{Appendix A. Supplementary data}

Supplementary data to this article can be found online at http://dx. doi.org/10.1016/j.scitotenv.2017.09.032. 


\section{References}

Aldaya, M.M., Garrido, A., Llamas, M.R., Varela-Ortega, C., Novo, P., Casado, R.R., 2010. In: Garrido, A., Llamas, M.R. (Eds.), Water Footprint and Virtual Water Trade in Spain. CRC Press, Balkema.

Allan, J.A., 1998. Virtual water: a strategic resource global solutions to regional deficits. Ground Water 36, 545-546.

Allen, R.G., Pereira, L.S., Raes, D., Smith, M., 1998. Crop evapotranspiration-guidelines for computing crop water requirements-FAO irrigation and drainage paper. Irrig. Drain. 56. FAO, Rome:p. 300 http://www.fao.org/docrep/X0490E/x0490e00.htm\#Contents.

Antonelli, M., Sartori, M., 2015. Unfolding the potential of the virtual water concept. What is still under debate? Environ. Sci. Pol. 50, 240-251.

Batjes, N.H., 2012. ISRIC-WISE Derived Soil Properties on a 5 by 5 Arc-minutes Global Grid (Ver. 1.2). Report 2012/01. ISRIC - World Soil Information, Wageningen, the Netherlands www.isric.org.

Carr, M.K.V., 2013. Crop yield response to water. FAO irrigation and drainage paper 66. By P. Steduto, T. C. Hsiao, E. Fereres and D. Raes. Rome, Italy: Food and Agriculture Organization of the United Nations (2012), pp. 500. Exp. Agric. 49:311. http:// www.fao.org/docrep/016/i2800e/i2800e00.htm.

Chapagain, A.K., Hoekstra, A.Y., 2008. The global component of freshwater demand and supply: an assessment of virtual water flows between nations as a result of trade in agricultural and industrial products. Water Int. 33, 19-32.

Chapagain, A.K., Hoekstra, A.Y., Savenije, H.H.G., 2006. Water saving through internationa trade of agricultural products. Hydrol. Earth Syst. Sci. 10, 455-468.

Chouchane, H., Hoekstra, A.Y., Krol, M.S., Mekonnen, M.M., 2015. The water footprint of Tunisia from an economic perspective. Ecol. Indic. 52, 311-319.

Chukalla, A.D., Krol, M.S., Hoekstra, A.Y., 2015. Green and blue water footprint reduction in irrigated agriculture: effect of irrigation techniques, irrigation strategies and mulching. Hydrol. Earth Syst. Sci. 19, 4877-4891.

Fader, M., Gerten, D., Thammer, M., Heinke, J., Lotze-Campen, H., Lucht, W., Cramer, W. 2011. Internal and external green-blue agricultural water footprints of nations, and related water and land savings through trade. Hydrol. Earth Syst. Sci. 15, 1641-1660.

FAOSTAT, 2015. Statistics Division. Food and Agriculture Organization of the United Nations (FAO), Rome, Italy.

Fracasso, A., Sartori, M., Schiavo, S., 2016. Determinants of virtual water flows in the Mediterranean. Science of The Total Environment 543, 1054-1062 Part B.

Hanasaki, N., Inuzuka, T., Kanae, S., Oki, T., 2010. An estimation of global virtual water flow and sources of water withdrawal for major crops and livestock products using a global hydrological model. J. Hydrol. 384, 232-244.

Harris, I., Jones, P.D., Osborn, T.J., Lister, D.H., 2014. Updated high-resolution grids of monthly climatic observations - the CRU TS3.10 Dataset. Int. J. Climatol. 34, 623-642.

Hoekstra, A.Y., 2013. The Water Footprint of Modern Consumer Society. Earthscan, from Routledge, London; New York.

Hoekstra, A.Y., 2017. Water footprint assessment: evolvement of a new research field. Water Resour. Manag. 1-21.

Hoekstra, A.Y., Chapagain, A.K., Aldaya, M.M., Mekonnen, M.M., 2011. The Water Footprint Assessment Manual: Setting the Global Standard. Earthscan.

Hoekstra, A.Y., Hung, P.Q., 2005. Globalisation of Water Resources: Global Virtual Water Flows in Relation to International Crop Trade. Elsevier.

Hoekstra, A.Y., Mekonnen, M.M., Chapagain, A.K., Mathews, R.E., Richter, B.D., 2012. Global monthly water scarcity: blue water footprints versus blue water availability. PLoS One 7, e32688.

Konar, M., Hussein, Z., Hanasaki, N., Mauzerall, D.L., Rodriguez-Iturbe, I., 2013. Virtual water trade flows and savings under climate change. Hydrol. Earth Syst. Sci. 17, 3219-3234.

Kumar, M.D., Singh, O.P., 2005. Virtual water in global food and water policy making: is there a need for rethinking? Water Resour. Manag. 19, 759-789.

Marianela, F., Dieter, G., Michael, K., Wolfgang, L., Wolfgang, C., 2013. Spatial decoupling of agricultural production and consumption: quantifying dependences of countries on food imports due to domestic land and water constraints. Environ. Res. Lett. 8, 014046
Marill, K.A., 2004. Advanced statistics: linear regression, part II: multiple linear regression. Acad. Emerg. Med. 11, 94-102.

Mekonnen, M.M., Hoekstra, A.Y., 2011. The green, blue and grey water footprint of crops and derived crop products. Hydrol. Earth Syst. Sci. 15, 1577-1600.

Mekonnen, M.M., Hoekstra, A.Y., 2014. Water conservation through trade: the case of Kenya. Water Int. 39, 451-468.

Melorose, J., Perroy, R., Careas, S., 2015. World Population Prospects: The 2015 Revision, Key Findings and Advance Tables. Working Paper No. ESA/P/WP.241 pp. 1-59.

Ministry of Agriculture, 1981-2010a. Yearbooks of Land Use, Tunis, Tunisia (in French).

Ministry of Agriculture, 1981-2010b. Yearbooks of Water Resources. General Directorate of Water Resources, Tunis, Tunisia (in French).

Ministry of Agriculture, 2000. Dates Cultivation and Irrigation Technics. Agency of Vulgarisation and Agricultural Training, Tunis, Tunisia (in French).

Ministry of Agriculture, 2007a. Wheat Cultivation and Irrigation Technics. Agency of Vulgarisation and Agricultural Training, Tunis, Tunisia (in French).

Ministry of Agriculture, 2007b. Olives Cultivation and Irrigation Technics. Agency of Vulgarisation and Agricultural Training, Tunis, Tunisia (in French).

Ministry of Agriculture, 2009. Season Potatoes Cultivation. Technical Center of Potatoes, Tunis, Tunisia (in French)

Ministry of Agriculture, 2011. Yearbook of Agricultural Statistics. General Directorate of Agricultural Development Studies, Tunis, Tunisia (in Arabic).

Mitchell, T.D. Carter, T.R., Jones, P.D., Hulme, M., New, M.A., 2004. Comprehensive set of high-resolution grids of monthly climate for Europe and the globe: the observed record (1901-2000) and 16 scenarios (2001-2100). Centre for Climate 1-30.

Monfreda, C., Ramankutty, N., Foley, J.A., 2008. Farming the planet: 2. Geographic distribution of crop areas, yields, physiological types, and net primary production in the year 2000. Glob. Biogeochem. Cycles 22.

Ouji, A., Rouaissi, M., Ben Salem, M., 2010. Dual Purpose Barley (Hordeum vulgare L.) Varietal Behaviour. INRAT Annu.

Portmann, F.T., Siebert, S., Döll, P., 2010. MIRCA2000-global monthly irrigated and rainfed crop areas around the year 2000: a new high-resolution data set for agricultural and hydrological modeling. Glob. Biogeochem. Cycles 24.

Schyns, J.F., Hoekstra, A.Y., 2014. The added value of water footprint assessment for national water policy: a case study for Morocco. PLoS One 9, e99705.

Steduto, P., Raes, D., Hsiao, T.C., Fereres, E., Heng, L.K., Howell, T.A., Evett, S.R., Rojas-Lara, B.A., Farahani, H.J., Izzi, G., Oweis, T.Y., Wani, S.P., Hoogeveen, J., Geerts, S., 2009. Concepts and applications of AquaCrop: The FAO crop water productivity model. In: Cao, W., White, J.W., Wang, E. (Eds.), Crop Modeling and Decision Support. Springer, Berlin Heidelberg, Berlin, Heidelberg, pp. 175-191.

Tamea, S., Carr, J.A., Laio, F., Ridolfi, L., 2014. Drivers of the virtual water trade. Water Resour. Res. 50, 17-28.

Vanuytrecht, E., Raes, D., Steduto, P., Hsiao, T.C., Fereres, E., Heng, L.K., Garcia Vila, M., Mejias Moreno, P., 2014. AquaCrop: FAO's crop water productivity and yield response model. Environ. Model Softw. 62, 351-360.

World Bank, 2016. Data retrieved November 7, 2016, From World Development Indicators Online (WDI) Database. [WWW Document], 2016.

Yang, H., Reichert, P., Abbaspour, K.C., Zehnder, A.J.B., 2003. A water resources threshold and its implications for food security. Environ. Sci. Technol. 37, 3048-3054.

Yang, H., Zehnder, A., 2007. "Virtual water": an unfolding concept in integrated water resources management. Water Resour. Res. 43, W12301.

Yang, H., Zehnder, A.J.B., 2002. Water scarcity and food import: a case study for southern Mediterranean countries. World Dev. 30, 1413-1430.

Zhuo, L., Mekonnen, M.M., Hoekstra, A.Y., 2016. The effect of inter-annual variability of consumption, production, trade and climate on crop-related green and blue water footprints and inter-regional virtual water trade: a study for China (1978-2008). Water Res. 94, 73-85.

Zwart, S.J., Bastiaanssen, W.G.M., de Fraiture, C., Molden, D.J., 2010. A global benchmark map of water productivity for rainfed and irrigated wheat. Agric. Water Manag. 97 (10), 1617-1627. 